\title{
Ultrastructure of spermiogenesis and mature spermatozoon of Triaenorhina rectangula (Cestoda: Cyclophyllidea: Paruterinidae)
}

\author{
Aneta Yoneva $^{1}$, Katia Georgieva ${ }^{1}$, Pavel N. Nikolov ${ }^{2}$, Yana Mizinska ${ }^{1}$, Boyko B. Georgiev ${ }^{2,3}$ \\ and Stoyanka R. Stoitsova ${ }^{4}$
}

\author{
${ }^{1}$ Institute of Experimental Pathology and Parasitology, Bulgarian Academy of Sciences, Acad. G. Bonchev Street, Block 25, 1113 \\ Sofia, Bulgaria; \\ ${ }^{2}$ Central Laboratory of General Ecology, Bulgarian Academy of Sciences, 2 Gagarin Street, 1113 Sofia, Bulgaria; \\ ${ }^{3}$ Department of Zoology, Natural History Museum, Cromwell Road, London SW7 5BD, UK; \\ ${ }^{4}$ Institute of Microbiology, Bulgarian Academy of Sciences, Acad. G. Bonchev Street, Block 26, 1113 Sofia, Bulgaria
}

\begin{abstract}
Ultrastructural characters of spermiogenesis and mature spermatozoon of Triaenorhina rectangula (Fuhrmann, 1908) are examined by transmission electron microscopy. Spermiogenesis follows the Bâ and Marchand's Type III spermiogenesis of cestodes. The process begins with the formation of a differentiation zone containing two centrioles and a cytoplasmic protrusion. The centrioles are associated with vestigial striated roots. One of the centrioles develops a free flagellum externally to the cytoplasmic protrusion. After a slight rotation, the free flagellum fuses with the cytoplasmic protrusion. In the final stage of spermiogenesis, a single crested body appears in the anterior part of the differentiating spermatozoon. The anterior extremity of the mature spermatozoon is characterised by an apical cone and a single crested body. The axoneme is of the 9+"1" trepaxonematan type. A periaxonemal sheath and electron-dense rods are described in some parts of the mature spermatozoon. The nucleus is electron-dense and spirally coiled around the axoneme. The cortical microtubules are spirally arranged at an angle of about $40^{\circ}$ to the spermatozoon axis. The present results show that the ultrastructural characters of spermiogenesis and mature spermatozoon of $T$. rectangula resemble most closely those in taeniids and metadilepidids. The comparison of these results with the only previous spermiological description of a paruterinid species reveals differences relative to the occurrence of filamentous rods of electron-dense material versus intracytoplasmic walls in the mature spermatozoon that may reflect the polyphyletic character of the Paruterinidae.
\end{abstract}

Key words: Cestoda, Cyclophyllidea, Paruterinidae, Triaenorhina rectangula, ultrastructure, spermiogenesis, spermatozoon

The usefulness of ultrastructural peculiarities of spermiogenesis and mature spermatozoa of cestodes as phylogenetic markers is widely recognised (Świderski 1968, 1970, 1986, Euzet et al. 1981, Bâ and Marchand 1995, Hoberg et al. 1997, 2001, Justine 1998, 2001). Prior to the application of such characters for resolving phylogenetic relationships among the families of the Cyclophyllidea, it is necessary to obtain comparative spermiological data for the families included in this order. Anonchotaenia globata (von Linstow, 1879) is the only member of the family Paruterinidae that has been studied from spermiological point of view (Yoneva et al. 2009). However, the paruterinids are believed to represent a polyphyletic group (Kornyushin 1989, Georgiev and Kornyushin 1994) and the genus Anonchotaenia Cohn, 1900 is often placed in a distinct family, i.e. Anonchotaeniidae (see Matevosyan 1969, Kornyushin 1989). Therefore, spermiological examinations of other paruterinids are needed. The aim of the present study is to describe the ultrastructure of spermiogenesis and the mature spermatozoon of Triaenorhina rectangula (Fuhrmann, 1908) (syn. Biuterina rectangula Fuhrmann, 1908), the type species of the genus Triaenorhina Spasskii et Shumilo, 1965. The latter genus has been classified in the family Biuterinidae of the superfamily Biuterinoidea by Kornyushin (1989) and in the family Paruterinidae (sensu lato) by Georgiev and Kornyushin (1994).

\section{MATERIALS AND METHODS}

Specimens of Triaenorhina rectangula were obtained from the small intestine of Coracias garrulus L. (Coraciiformes, Coraciidae) at Kalimok Biological Station $\left(44^{\circ} 01^{\prime} \mathrm{N}, 26^{\circ} 26^{\prime} \mathrm{E}\right)$ near the village of Nova Cherna, Silistra Region, Bulgaria. Strobilar fragments consisting of mature proglottides were separated and fixed in $4 \%$ glutaraldehyde in $0.2 \mathrm{M}$ cacodylate buffer at $\mathrm{pH} 7.2$ for $4 \mathrm{~h}$, rinsed overnight in $0.2 \mathrm{M}$ cacodylate buffer, postfixed in cold $\left(4^{\circ} \mathrm{C}\right) 1 \%$ osmium tetroxide in the same buffer for $1 \mathrm{~h}$, dehydrated in ethanol series and propylene oxide and em- 
bedded in Durcupan. Ultrathin sections through testes and vas deferens were cut on an Ultratome LKBIII, placed on copper grids and double stained with uranyl acetate and lead citrate. The grids were examined under a JEOL 1200 transmission electron microscope at $80 \mathrm{kV}$.

\section{RESULTS \\ Spermiogenesis}

Spermiogenesis of Triaenorhina rectangula is illustrated on Figs. 1A-F, 2A-G and 3A-E. It begins with the formation of a conical differentiation zone situated at the periphery of each spermatid (Fig. 1A). Each differentiation zone is characterised by the presence of arching membranes and by a surrounding submembranous layer of cortical microtubules. The newly formed differentiation zone contains a large nucleus (Fig. 1B), a pair of centrioles and a cytoplasmic protrusion arising between them (Fig. 1C). The centrioles are separated from one another and each is associated with vestigial striated roots (Fig. 1C, D). During the initial stage of spermiogenesis, one of the centrioles forms a free flagellum that grows externally to the cytoplasmic protrusion (Fig. 1E). The other centriole remains oriented in a cytoplasmic bud and is aborted in a later stage of spermiogenesis. The cortical microtubules in the cytoplasmic protrusion are elongated parallel to the sperm axis (Figs. 1F, 2A). The free flagellum undergoes a slight rotation, becomes parallel to the cytoplasmic protrusion and fuses with it proximo-distally (Figs. 1E, F, 2A). Thereafter, the nucleus elongates and migrates into the cytoplasmic protrusion (Fig. 2B, C). Electron-dense material is observed in the periphery of the spermatid (Fig. 2D, E). Spermiogenesis terminates with the formation of a crested body, constriction of the ring of arching membranes and detachment of the young spermatozoon from the residual cytoplasm (Fig. 2F, G).

\section{Spermatozoon}

The ultrastructural organisation of the mature spermatozoon of Triaenorhina rectangula is illustrated on Figs. $4 \mathrm{~A}-\mathrm{I}$ and $5 \mathrm{I}-\mathrm{IV}$. It is a filiform cell tapering at both extremities. From the anterior to the posterior extremities of the gamete, it is possible to distinguish four regions with distinct ultrastructural characters.

Region I (Fig. 4A-D) represents the anterior part of the spermatozoon. This region is capped by an apical cone of electron-dense material (Fig. 4A) and contains a single helicoidal crested body, which is $50 \mathrm{~nm}$ thick (Fig. 4A-D). The latter is built up by microtubules combined with electron-dense material on the edge (Fig. 4C, D). The axoneme is of the $9+$ " 1 " trepaxonematan pattern and centrally located. It is surrounded by a layer of slightly electron-dense cytoplasm. The cortical microtubules constitute a submembranous electron-dense layer and are twisted at an angle of about $40^{\circ}$ to the spermatozoon axis.
Region II (Fig. 4D, E) is characterised by the absence of crested body. The axoneme is additionally surrounded by a periaxonemal sheath of electron-dense material and the cytoplasm is divided by filamentous rods of electrondense material (Fig. 4D, E).

Region III (Fig. 4F-H) corresponds to the nucleated area of the mature spermatozoon. It is characterised by the presence of the nucleus, which is spirally coiled around the axoneme (Fig. 4G, H). It is interposed between the periaxonemal sheath and the cortical microtubules (Fig. 4F, G). Where the nucleus approaches the plasma membrane, no microtubules are present (Fig. 4G).

Region IV (Fig. 4H, I) corresponds to the posterior part of the spermatozoon. The beginning of this region is marked by the disappearance of the nucleus, periaxonemal sheath and electron-dense rods (Fig. 4H). The disorganisation of the axoneme is preceded by the disappearance of cortical microtubules (Fig. 4I).

\section{DISCUSSION}

\section{Spermiogenesis}

Spermiogenesis of Triaenorhina rectangula follows the Type III according to the classification proposed by Bâ and Marchand (1995). This includes the formation of a differentiation zone containing two centrioles and a cytoplasmic protrusion. One of the centrioles develops a free flagellum that grows parallel to the cytoplasmic protrusion, with a subsequent proximodistal fusion between them. We also observed that (1) the centrioles are associated with multiple vestigial striated roots and (2) the free flagellum undergoes a slight rotation prior to its fusion with the cytoplasmic protrusion.

In spermiogenesis of $T$. rectangula, each of the centrioles is associated with several thin striated roots, the so-called "vestigial striated roots". The presence of numerous vestigial roots jointed with one centriole has been observed in anoplocephalids Anoplocephaloides dentata (see Miquel and Marchand 1998), Gallegoides arfaai (see Miquel et al. 2005a) and Mosgovoyia ctenoides (see Eira et al. 2006), dipylidiid Dipylidium caninum (see Miquel et al. 1998, 2005b), paruterinid Anonchotaenia globata (see Yoneva et al. 2009), metadilepidid Skrjabinoporus merops (see Yoneva et al. 2006a) and taeniid Taenia taeniaeformis (see Miquel et al. 2009a). Miquel et al. (2005a) considered the vestigial roots as degenerated typical striated roots, which have undergone a progressive reduction in the cyclophyllideans towards their absence in more evolved cestodes.

The present results increase the number of cyclophyllidean species in which a slight flagellar rotation has been observed. The previously described spermiogenesis in the paruterinid A. globata (see Yoneva et al. 2009), as well as in the catenotaeniid Catenotaenia pusilla (see Hidalgo et al. 2000) and the taeniids Taenia parva (see Ndiaye et 

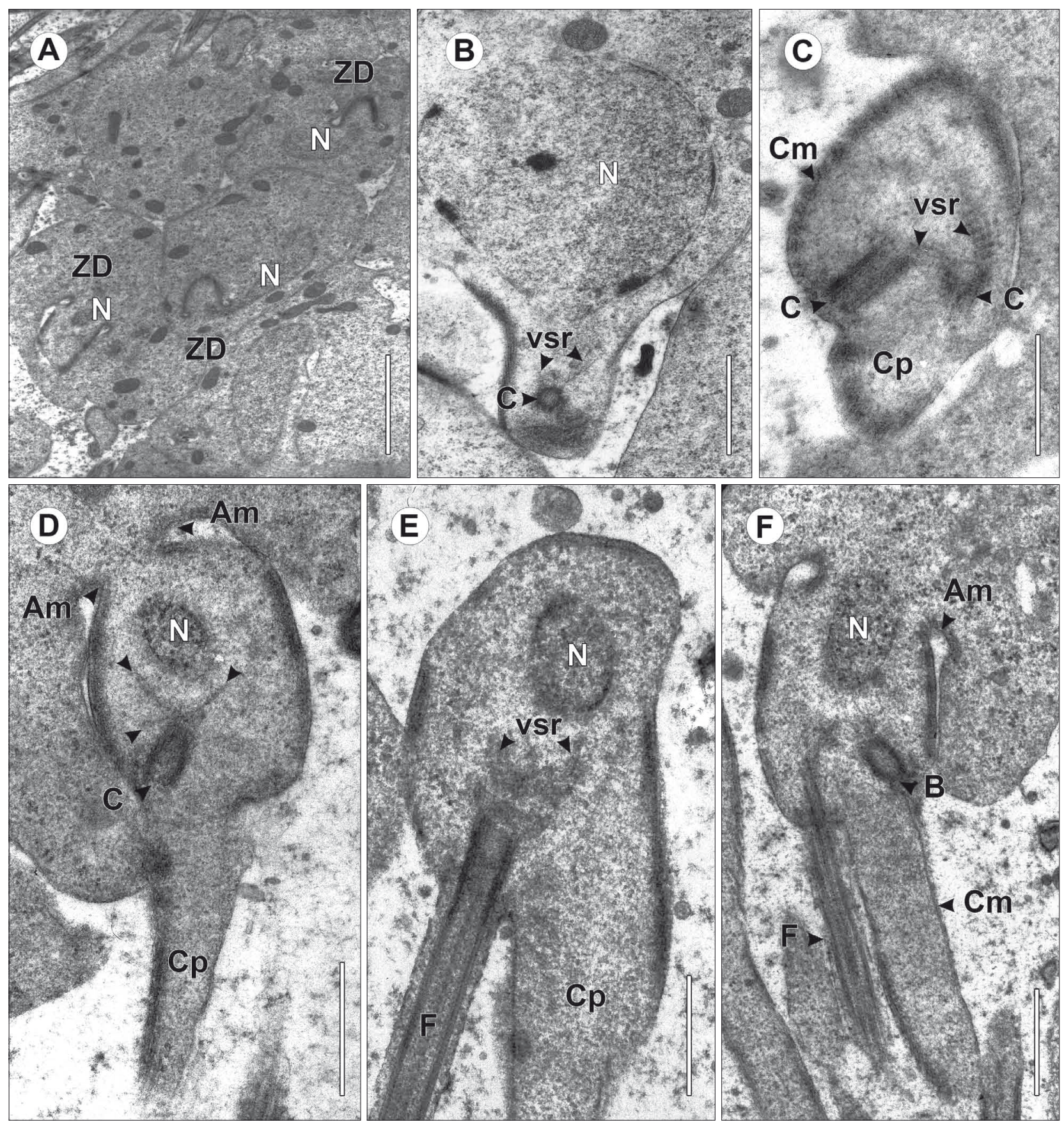

Fig. 1. Early stages of spermiogenesis in Triaenorhina rectangula. A - Section of a testis showing part of a rosette of spermatids with numerous zones of differentiation (ZD). B - Longitudinal section of a differentiation zone in the initial stage of spermiogenesis. C, D - Longitudinal sections of the differentiation zone illustrating the centrioles (C) associated with vestigial striated roots (vsr). Arrowheads indicate multiple vestigial striated roots. $\mathbf{E}$ - Longitudinal section of a zone of differentiation showing the slight rotation of the free flagellum (F) with the cytoplasmic protrusion (Cp). F - Longitudinal section of a differentiation zone showing the parallel free flagellum (F) before its fusion with the cytoplasmic protrusion. Abbreviations: Am - arching membrane; B - cytoplasmic bud; $\mathrm{C}$ - centriole; $\mathrm{Cm}$ - cortical microtubules; $\mathrm{Cp}$ - cytoplasmic protrusion; $\mathrm{F}$ - free flagellum; $\mathrm{N}$ - nucleus; vsr - vestigial striated roots; $\mathrm{ZD}$ - zone of differentiation. Scale bars: $\mathrm{A}=2 \mu \mathrm{m} ; \mathrm{B}, \mathrm{C}, \mathrm{D}=0.5 \mu \mathrm{m} ; \mathrm{E}=0.6 \mu \mathrm{m} ; \mathrm{F}=0.8 \mu \mathrm{m}$.

al. 2003a) and T. taeniaeformis (see Miquel et al. 2009a), exhibits slight flagellar rotation. In the other examined cyclophyllideans, in which spermiogenesis is also of Type III, i.e. taeniids Taenia hydatigena (see Featherston 1971),
T. solium (see Willms et al. 2003) and T. crassiceps (see Willms et al. 2004), dipylidiids D. caninum (see Miquel and Marchand 1997), Joyeuxiella echinorhynchoides and J. pasqualei (see Ndiaye et al. 2003b), nematotaeniid 


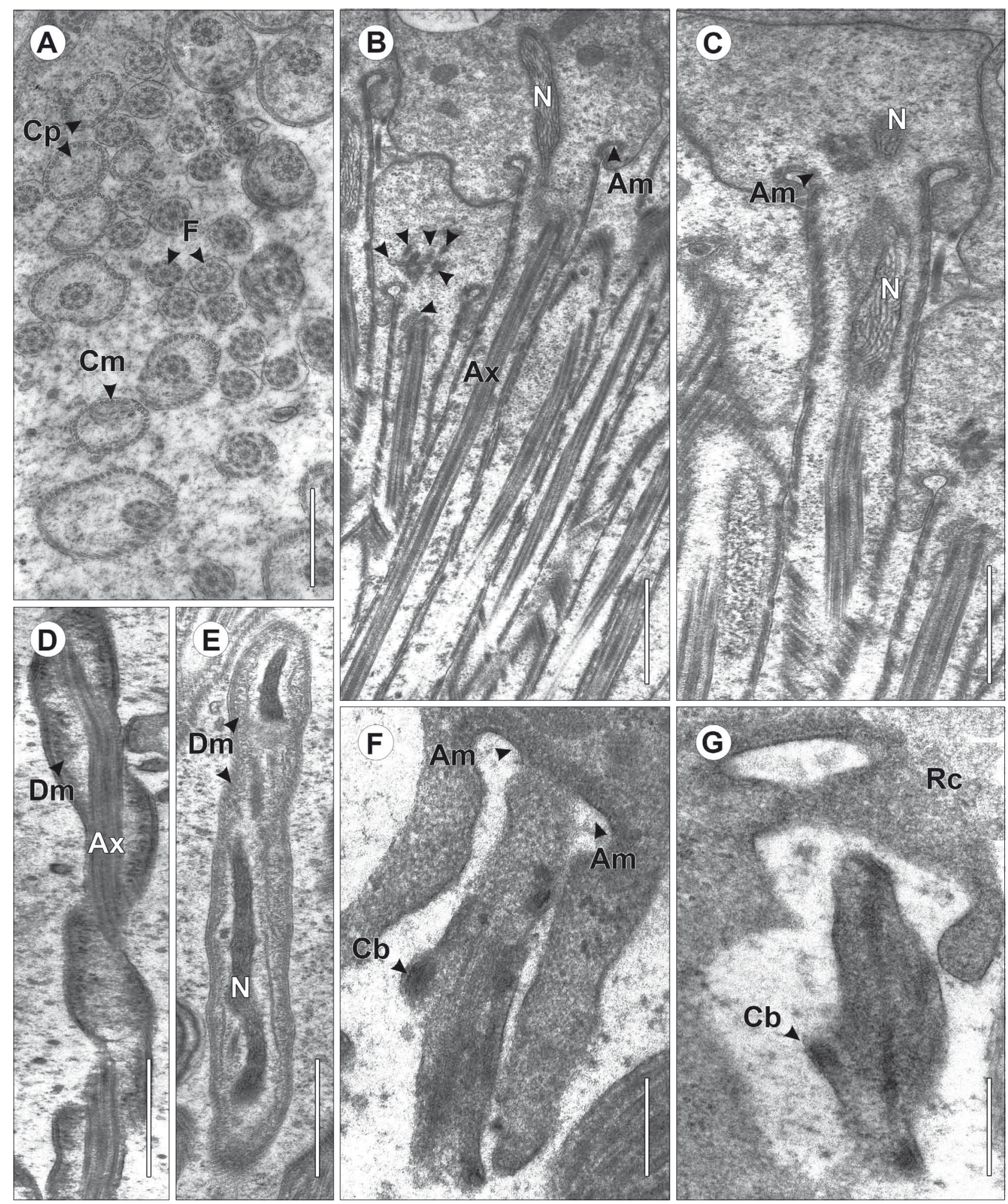

Fig. 2. Advanced stages of spermiogenesis in Triaenorhina rectangula. A - Several cross-sections of spermatids in stages before and after proximodistal fusion between the free flagellum (F) and the cytoplasmic protrusion (Cp). B - Longitudinal section of differentiation zones showing the beginning of the migration of the nucleus $(\mathrm{N})$ into the spermatid. Arrowheads indicate numerous vestigial striated roots. $\mathbf{C}$ - Longitudinal section of a differentiation zone illustrating the advanced stage of the migration of the nucleus $(\mathrm{N})$. D, $\mathbf{E}$ - Longitudinal sections demonstrating the presence of dense material (Dm) in the periphery of the spermatid. $\mathbf{F}$ - Longitudinal section of a spermatid demonstrating the formation of the crested body $(\mathrm{Cb})$. $\mathbf{G}$ - Longitudinal section of a spermatid in the final stage of spermiogenesis illustrating the constriction of the ring of arching membranes. Abbreviations: Am - arching membrane; $\mathrm{Ax}$ - axoneme; $\mathrm{Cb}$ - crested body; $\mathrm{Cm}$ - cortical microtubules; $\mathrm{Cp}$ - cytoplasmic protrusion; $\mathrm{Dm}$ - dense material; $\mathrm{F}$ - free flagellum; $\mathrm{N}$ - nucleus; Rc - residual cytoplasm. Scale bars: A, C, D = 0.6 $\mu \mathrm{m} ; \mathrm{B}=0.8 \mu \mathrm{m} ; \mathrm{E}=0.4 \mu \mathrm{m} ; \mathrm{F}, \mathrm{G}=0.2 \mu \mathrm{m}$. 

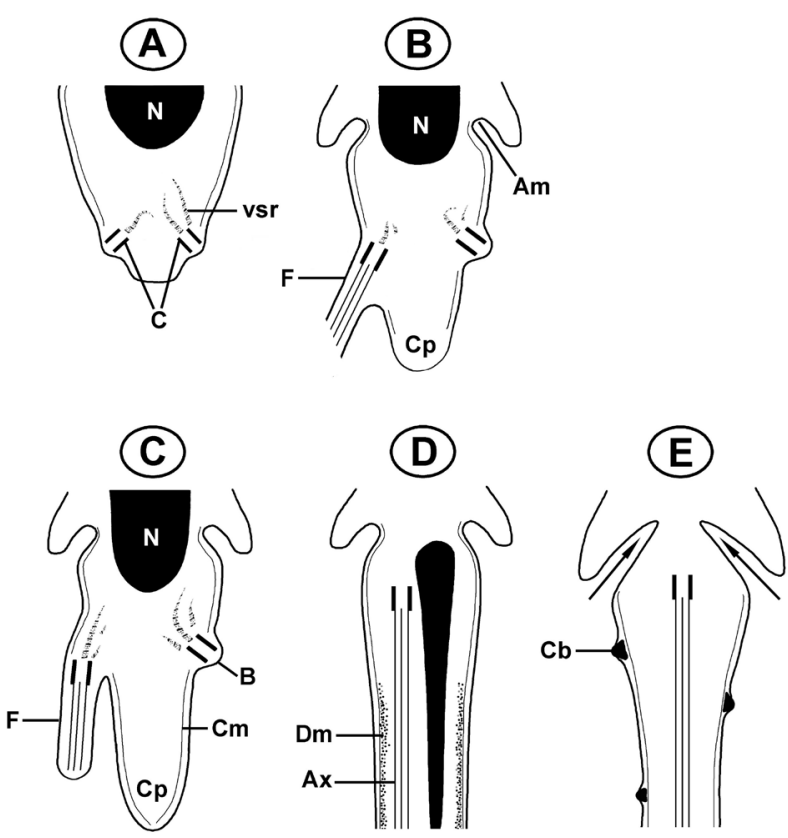

Fig. 3. A-E - Schematical presentation of the main stages of spermiogenesis in Triaenorhina rectangula. Abbreviations: $\mathrm{Am}$ - arching membrane; Ax - axoneme; $\mathrm{B}$ - cytoplasmic bud; $\mathrm{C}$ - centriole; $\mathrm{Cb}$ - crested body; $\mathrm{Cm}$ - cortical microtubules; $\mathrm{Cp}$ - cytoplasmic protrusion; Dm - dense material; $\mathrm{F}$ - free flagellum; $\mathrm{N}$ - nucleus; vsr - vestigial striated roots.

Nematotaenia chantalae (see Mokhtar-Maamouri and Azzouz-Draoui 1990), anoplocephalid Mathevotaenia herpestis (see Bâ and Marchand 1994a), and davaineids Raillietina tunetensis (see Bâ and Marchand 1994b) and R. micracantha (see Miquel et al. 2009b), the free flagellum develops parallel to the cytoplasmic protrusion and there is no rotation of the flagellum in the course of spermiogenesis.

In conclusion, the most characteristic features of spermiogenesis in T. rectangula are the presence of vestigial striated roots associated with the centrioles and the slight rotation of the free flagellum prior its proximodistal fusion with the cytoplasmic protrusion.

\section{Spermatozoon}

The anterior extremity of the mature spermatozoon of T. rectangula is characterised by the presence of a single crested body. It initiates its helical course along the spermatozoon at the level of the apical cone. The crested body or bodies always mark the anterior extremity of the spermatozoon (Bâ et al. 1991) and has been considered as a synapomorphic character for a part of the Eucestoda (Justine 2001). In the Cyclophyllidea, most of the species have one or two crested bodies on the anterior spermatozoon extremity. More than two crested bodies were described in the sperm cells of several species: Killigrewia delafondi ( 5 crested bodies) (see Bâ and March- and 1994c), Cladogynia serrata (6 crested bodies) (see Bâ and Marchand 1993), Rodentolepis microstoma (6 crested bodies) (see Bâ and Marchand 1998), Sudarikovina taterae ( 7 crested bodies) (see Bâ et al. 2000), Rodentolepis straminea ( 8 crested bodies) (see Bâ and Marchand 1996), Echinocotyle dolosa (8 crested bodies) (see Bâ et al. 2002), Rodentolepis myoxi (9 crested bodies) (see Miquel et al. 2007), Hymenolepis sulcata (9 crested bodies) (see Miquel et al. 2007), Rodentolepis fraterna (10 crested bodies) (see Miquel et al. 2007) and Rodentolepis nana (12 crested bodies) (see Bâ and Marchand 1992a).

The presence of twisted cortical microtubules was considered as a synapomorphy for the Cyclophyllidea plus Tetrabothriidea (Justine 1998, 2001). The angle of twisting of the submembranous layer of cortical microtubules varies from $15^{\circ}$ to $60^{\circ}$. This angle in the mature spermatozoon of $T$. rectangula is of about $40^{\circ}$. In the mature spermatozoon of the paruterinid $A$. globata, this angle has been estimated to be of about $35^{\circ}$ (see Yoneva et al. 2009).

The mature spermatozoon of $T$. rectangula is characterised by the presence of a periaxonemal sheath and filamentous rods of electron-dense material. A periaxonemal sheath surrounding the axoneme has been described in the mature spermatozoa of species belonging to 9 families: Anoplocephalidae (see Bâ and Marchand 1992b, 1994a, d), Catenotaeniidae (see Miquel et al. 1997, Hidalgo et al. 2000), Davaineidae (see Bâ and Marchand 1994b, e, Bâ et al. 2005a, b, Miquel et al. 2009b), Dilepididae (see Świderski et al. 2000, Yoneva et al. 2006b), Taeniidae (see Featherston 1971, Miquel et al. 2000, Ndiaye et al. 2003a, Willms et al. 2003, 2004, Miquel et al. 2009c), Dipylidiidae (see Miquel and Marchand 1997, Ndiaye et al. 2003b), Metadilepididae (see Yoneva et al. 2006a), Gryporhynchidae (see Yoneva et al. 2008) and Paruterinidae (see Yoneva et al. 2009).

One important item is the way the periaxonemal sheath communicates with the periphery of the sperm cell. In some spermatozoa, packets of electron-dense filaments protrude outwards from the periaxonemal sheath. This type of structures have been named differently; we accept the term "electron-dense rods" used by Świderski et al. (2000). Where transverse sections of these are present in electron micrographs, the rods appear dot-like. The other way the periaxonemal sheath may be bound to sperm periphery is by membranous structures first described in Avitellina centripunctata (Bâ and Marchand 1994f) and named "intracytoplasmic walls". In micromorphological descriptions of cestode spermatozoa, regarding these two distinct structures there is sometimes inconsistency between the terminology applied in the text and the actual electron micrographic data. For this reason, the following comments are based on re-examination of published electron micrographs. 


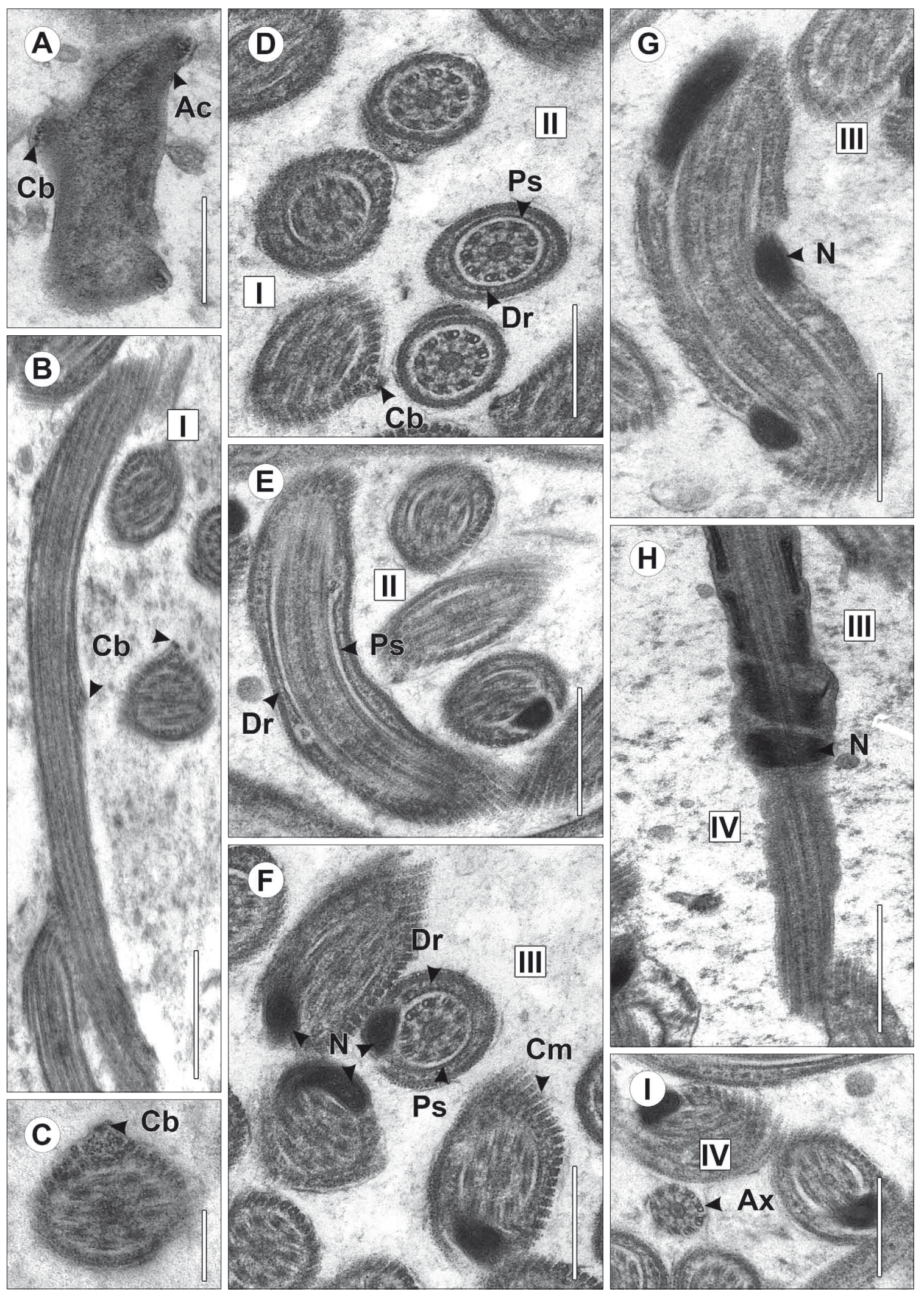


To date, electron-dense rods have been illustrated in seven species belonging to three families: Dilepis undula (see Świderski et al. 2000), Taenia hydatigena (see Featherston 1971), T. mustelae (see Miquel et al. 2000), T. par$v a$ (see Ndiaye et al. 2003a), T. crassiceps (see Willms et al. 2004), T. taeniaeformis (see Miquel et al. 2009c) and Skrjabinoporus merops (see Yoneva et al. 2006a).

In the other paruterinid studied, Anonchotaenia globata (see Yoneva et al. 2009), the periaxonemal sheath and the cortical microtubules are connected by transverse intracytoplasmic walls. This character is also visualised in the anoplocephalids Avitellina centripunctata, Inermicapsifer guineensis and I. madagascariensis (see Bâ and Marchand 1994d, f) and all davaineid species studied, i.e. Raillietina tunetensis, Cotugnia polyacantha, $R$. baeri, Paroniella reynoldsae and $R$. micracantha (see Bâ and Marchand 1994b, e, Bâ et al. 2005a, b, Miquel et al. 2009b).

\section{Taxonomic and phylogenetic inference}

The ultrastructural characters of spermiogenesis and mature spermatozoon of Triaenorhina rectangula resemble those of the species of the families Taeniidae and Metadilepididae, which are currently considered phylogenetically close to the Paruterinidae (Hoberg et al. 1999). The comparison of the spermiological characters of T. rectangula with those of the taeniids Taenia hydatigena (see Featherston 1971), T. mustelae (see Miquel et al. 2000), T. parva (see Ndiaye et al. 2003a), T. crassiceps (see Willms et al. 2004) and T. taeniaeformis (see Miquel et al. 2009a, c) and the metadilepidid Skrjabinoporus merops (see Yoneva et al. 2006a) reveals the same ultrastructural organisation. All these species exhibit similarities in spermiogenesis, i.e. the presence of vestigial striated roots and mature spermatozoa, i.e. the presence of a single crested body, periaxonemal sheath, and filamentous rods of electron-dense material.

The presence of slight flagellar rotation during spermiogenesis confirms relationships with Anonchotaenia globata (see Yoneva et al. 2009), metadilepidids (see Yoneva et al. 2006a), taeniids (Ndiaye et al. 2003a, Miquel et al. 2009a) and catenotaeniids (Hidalgo et al. 2000).

The ultrastructural characters associated with spermiogenesis and the mature spermatozoon of the two studied paruterinid species are: (1) spermiogenesis of Type III, (2) presence of vestigial striated roots, (3) presence of a slight rotation prior to the proximodistal fusion, (4) a single
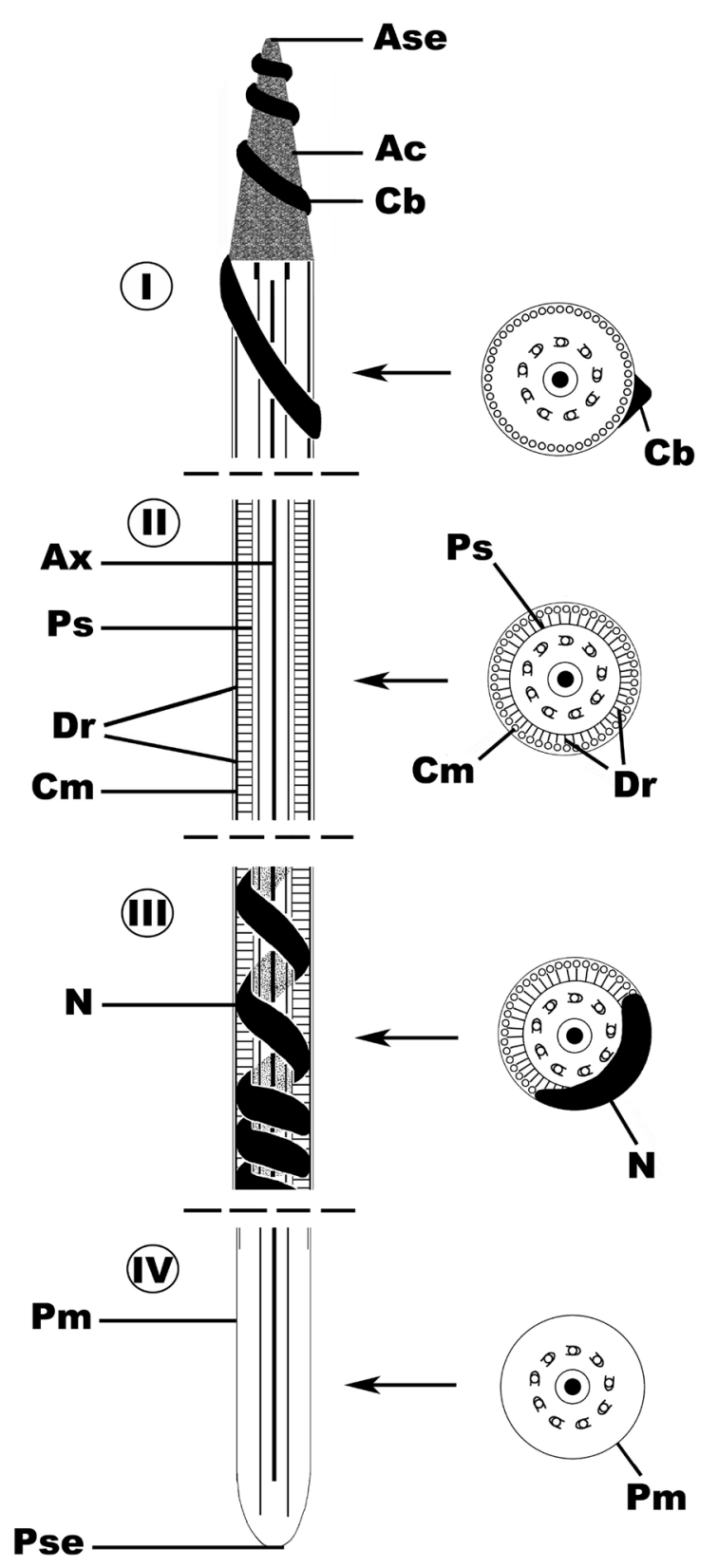

Fig. 5. I-IV - Schematical reconstruction of the mature spermatozoon of Triaenorhina rectangula. In order to make the diagram clearer, the twisted cortical microtubules are presented as parallel in cross-sections. Abbreviations: Ac - apical cone; Ase - anterior spermatozoon extremity; $\mathrm{Ax}$ - axoneme; $\mathrm{Cb}$ - crested body; $\mathrm{Cm}$ - cortical microtubules; $\mathrm{Dr}$ - electron-dense rods; $\mathrm{N}$ - nucleus; Pm - plasma membrane; $\mathrm{Ps}$ - periaxonemal sheath; Pse - posterior spermatozoon extremity.

Fig. 4. Mature spermatozoon of Triaenorhina rectangula. A - Longitudinal section of Region I at the level of the anterior spermatozoon extremity showing the apical cone $(\mathrm{Ac})$ and a single crested body $(\mathrm{Cb})$. B - Longitudinal section of Region I of a mature spermatozoon demonstrating the presence of a single crested body $(\mathrm{Cb})$. $\mathbf{C}$ - Cross-section of Region I at the level of the crested body $(\mathrm{Cb})$. D - Cross-sections of Region I and Region II of a mature spermatozoon. $\mathbf{E}$ - Longitudinal section of Region II of a mature spermatozoon. F - Cross-sections of Region III of a mature spermatozoon. G - Longitudinal section of Region III of a mature spermatozoon. H - Longitudinal section at the level of transition between Region III and Region IV. I - Cross-section of Region IV of a mature spermatozoon. Abbreviations: $\mathrm{Ac}$ - apical cone; $\mathrm{Cb}$ - crested body; $\mathrm{Cm}$ - cortical microtubules; $\mathrm{Dr}$ - electron-dense rods; $\mathrm{N}$ - nucleus; Ps - periaxonemal sheath. I-IV - regions along the mature spermatozoon length. Scale bars: A, B, H = 0.3 $\mu$ m; $\mathrm{C}, \mathrm{D}, \mathrm{F}=0.2 \mu \mathrm{m} ; \mathrm{E}, \mathrm{G}, \mathrm{I}=0.4 \mu \mathrm{m}$. 
crested body, (5) a periaxonemal sheath, (6) a nucleus spirally coiled around the axoneme and (7) absence of dense granules. The present results demonstrate differences within the family relative to the presence of filamentous rods of electron-dense material in the mature sperm of T. rectangula and intracytoplasmic walls in A. globata.

As mentioned above, the position of the genera Anonchotaenia and Triaenorhina in the same family is disputable (Matevosyan 1969, Kornyushin 1989, Georgiev and Kornyushin 1994). The comparative spermiological data do not provide resolution allowing their definitive allocation in separate phyletic lineages within the order Cyclophyllidea. The main difference, i.e. the presence of filamentous rods of electron-dense material in the spermatozoon of $T$. rectangula and intracytoplasmic walls in the spermatozoon of Anonchotaenia globata, needs to be further assessed having in view the distribution of these characters across the Cyclophyllidea. The occurrence of intracytoplasmic walls in Anonchotaenia may show affinities with davaineids, inermicapsiferine anoplocephalids and some thysanosomatine anoplocephalids, which also have intracytoplasmic walls in mature spermatozoa (Bâ and Marchand 1994b, d, e, f, Bâ et al. 2005a, b, Miquel et al. 2009b), thus corroborating with the polyphyletic origin of the family Paruterinidae in its widely accepted composition (e.g. Georgiev and Kornyushin 1994).

Acknowledgements. We are grateful to Dr. P. Zehtindjiev (Institute of Zoology, Bulgarian Academy of Sciences) for his help in the field studies at Kalimok Biological Station. This study was supported by the National Science Fund, Ministry of Education and Science of the Republic of Bulgaria, Grant B-1539/05 and Grant DO/02-271/18.12.08.

\section{REFERENCES}

BÂ A., BÂ C.T., Marchand B. 2000: Ultrastructure of spermiogenesis and the spermatozoon of the Sudarikovina taterae (Cestoda, Cyclophyllidea, Anoplocephalidae) intestinal parasite of Tatera gambiana (Rodentia, Gerbillidae). J. Submicrosc. Cytol. Pathol. 32: 137-144.

BÂ A., BÂ C.T., Marchand B. 2002: Ultrastructural study of the spermatozoon of Echinocotyle dolosa (Cestoda, Cyclophyllidea, Hymenolepididae). Acta Parasitol. 47: 131-136.

BÂ C.T., BÂ A., Marchand B. 2005a: Ultrastructure of the spermatozoon of Raillietina (Raillietina) baeri (Cyclophyllidea, Davaineidae) an intestinal parasite of the multimammate rat, Mastomys huberti (Rodentia, Muridae). Parasitol. Res. 97: 173-178.

BÂ C.T., BÂ A., Marchand B. 2005b: Ultrastructure of the spermatozoon of Paroniella reynoldsae (Cyclophyllidea, Davaineidae) an intestinal parasite of Corvus albus (Aves, Corvidae). Acta Parasitol. 50: 208-214.

BÂ C.T., Marchand B. 1992a: Reinvestigation of the ultrastructure and the spermatozoon of Hymenolepis nana (Cestoda, Cyclophyllidea), parasite of the small intestine of Rattus rattus. Mol. Reprod. Dev. 33: 39-45.

BÂ C.T., Marchand B. 1992b: Ultrastructural particularities of the spermatozoon of Stilesia globipunctata (Cestoda) parasite of the small intestine of sheep and goats in Senegal. J. Submicrosc. Cytol. Pathol. 24: 29-34.

BÂ C.T., Marchand B. 1993: Ultrastructure of the Retinometra serrata spermatozoon (Cestoda) intestinal parasite of turtledoves in Senegal. J. Submicrosc. Cytol. Pathol. 25: 233-238.

BÂ C.T., Marchand B. 1994a: Ultrastructure of spermiogenesis and the spermatozoon of Mathevotaenia herpestis (Cestoda), intestinal parasite of Atelerix albiventris in Senegal. Acta Zool. (Stockh.) 75: 167-175.

BÂ C.T., Marchand B. 1994b: Ultrastructure of spermiogenesis and the spermatozoon of Raillietina (Raillietina) tunetensis (Cyclophyllidea, Davaineidae), intestinal parasite of turtle doves in Senegal. Int. J. Parasitol. 24: 237-248.

BÂ C.T., Marchand B. 1994c: Ultrastructure of spermiogenesis and the spermatozoon of Aporina delafondi (Cyclophyllidea, Anoplocephalidae), intestinal parasite of turtle-doves in Senegal. Int. J. Parasitol. 24: 225-235.

BÂ C.T., Marchand B. 1994d: Comparative ultrastructure of the spermatozoa of Inermicapsifer guineensis and I. madagascarien- sis (Cestoda, Anoplocephalidae, Inermicapsiferinae), intestinal parasites of rodents in Senegal. Can. J. Zool. 72: 1633-1638.

BÂ C.T., Marchand B. 1994e: Similitude ultrastructurale des spermatozoïdes de quelques Cyclophyllidea. Parasite 1: 51-55.

BÂ C.T., Marchand B. 1994f: Ultrastructure of the spermatozoon of Avitellina centripunctata (Cestoda, Cyclophyllidea) a parasite of the small intestine of cattle in Senegal. Acta Zool. (Stockh.) 75: $161-166$.

BÂ C.T., Marchand B. 1995: Spermiogenesis, spermatozoa and phyletic affinities in the Cestoda. Mém. Mus. Natl. Hist. Nat. 166: 87-95.

BÂ C.T., Marchand B. 1996: Ultrastructure of spermatozoon of Hymenolepis straminea (Cyclophyllidea, Hymenolepididae) intestinal parasite of Arvicanthis niloticus in Senegal. Invertebr. Reprod. Dev. 29: 243-247.

BÂ C.T., Marchand B. 1998: Ultrastructure of spermiogenesis and the spermatozoon of Vampirolepis microstoma intestinal parasite of Rattus rattus. Microsc. Res. Tech. 42: 218-225.

BÂ C.T., Marchand B., Mattei X. 1991: Demonstration of the orientation of the Cestodes spermatozoon illustrated by the ultrastructural study of spermiogenesis of a Cyclophyllidea: Thysaniezia ovilla Rivolta, 1874. J. Submicrosc. Cytol. Pathol. 23: 606-612.

Eira C., Miquel J., Vingada J., Torres J. 2006: Spermiogenesis and spermatozoon of the cestode Mosgovoyia ctenoides (Cyclophyllidea: Anoplocephalidae), an intestinal parasite of Oryctolagus cuniculus (Lagomorpha, Leporidae). J. Parasitol. 92: 708-718.

Euzet L., Świderski Z., Mokhtar-Maamouri F. 1981: Ultrastructure comparée du spermatozoïde des Cestodes. Relations avec la phylogénèse. Ann. Parasitol. Hum. Comp. 56: 247-259.

Featherston D.W. 1971: Taenia hydatigena III. Light and electron microscopy study of spermiogenesis. Z. Parasitenkd. 37: $148-168$.

Georgiev B.B., Kornyushin V.V. 1994: Family Paruterinidae Fuhrmann, 1908 (sensu lato). In: L.F. Khalil, A. Jones and R.A. Bray (Eds.), Keys to the Cestode Parasites of Vertebrates. CAB International, Wallingford, UK, pp. 559-584.

Hidalgo C., Miquel J., Torres J., Marchand B. 2000: Ultrastructural study of spermiogenesis and the spermatozoon in Catenotaenia pusilla, an intestinal parasite of Mus musculus. J. Helminthol. 74: 73-81. 
Hoberg E.P., Jones A., Bray R.A. 1999: Phylogenetic analysis among the families of the Cyclophyllidea (Eucestoda) based on comparative morphology, with new hypotheses for co-evolution in vertebrates. Syst. Parasitol. 42: 51-73.

Hoberg E.P., Mariaux J., Brooks D.R. 2001: Phylogeny among the orders of the Eucestoda (Cercomeromorphae): integrating morphology, molecules and total evidence. In: D.T.J. Littlewood and R.A. Bray (Eds.), Interrelationships of the Platyhelminthes. Taylor and Francis, London, pp. 112-126.

Hoberg E.P., Mariaux J., Justine J.-L., Brooks D.R., Weekes P.J. 1997: Phylogeny of the Eucestoda (Cercomeromorphae) based on comparative morphology: historical perspectives and a new working hypothesis. J. Parasitol. 83: 1128-1147.

Justine J.-L. 1998: Spermatozoa as phylogenetic characters for the Eucestoda. J. Parasitol. 84: 385-408

JUSTINE J.-L. 2001: Spermatozoa as phylogenetic characters for the Platyhelminthes. In: D.T.J. Littlewood and R.A. Bray (Eds.), Interrelationships of the Platyhelminthes. Taylor and Francis, London, pp. 231-238.

Kornyushin V.V. 1989: [Fauna of Ukraine. Vol. 33. Monogenea and Cestoda. Part 3. Davaineoidea. Biuterinoidea. Paruterinoidea.] Naukova Dumka, Kiev, 252 pp. (In Russian.)

Matevosyan E.M. 1969: [Paruterinoidea - tapeworms of domestic and wild birds.] In: K.I. Skryabin (Ed.), Osnovy Tsestodologii, Vol. 7. Nauka, Moscow, 304 pp. (In Russian.)

Miquel J., BÂ C.T., Marchand B. 1997: Ultrastructure of the spermatozoon of Skrjabinotaenia lobata (Cyclophyllidea, Catenotaeniidae), intestinal parasite of Apodemus sylvaticus (Rodentia, Muridae). J. Submicrosc. Cytol. Pathol. 29: 521-526.

Miquel J., BÂ C.T., Marchand B. 1998: Ultrastructure of spermiogenesis of Dipylidium caninum (Cestoda, Cyclophyllidea, Dipylidiidae), an intestinal parasite of Canis familiaris. Int. J. Parasitol. 28: 1453-1458.

Miquel J., Foronda P., Torres J., Świderski Z., Feliu C. 2009c: Ultrastructural study of the spermatozoon of Taenia taeniaeformis (Batsch, 1786) (Cestoda, Cyclophyllidea, Taeniidae), an intestinal parasite of Felis catus from La Palma (Canary Islands, Spain). Parasitol. Res. 104: 1477-1483.

Miquel J., Hidalgo C., Feliu C., Marchand B. 2000: Sperm ultrastructure of Taenia mustelae (Cestoda, Taeniidae), an intestinal parasite of the weasel, Mustela nivalis (Carnivora). Invertebr. Reprod. Dev. 38: 43-51.

Miquel J., Marchand B. 1997: Ultrastructure of spermatozoon of Dipylidium caninum (Cestoda, Cyclophyllidea, Dilepididae), an intestinal parasite of Canis familiaris. Parasitol. Res. 83: 349355.

Miquel J., Marchand B. 1998: Ultrastructure of spermiogenesis and the spermatozoon of Anoplocephaloides dentata (Cestoda, Cyclophyllidea, Anoplocephalidae), an intestinal parasite of Arvicolidae rodents. J. Parasitol. 84: 1128-1136.

Miquel J., Ndiaye P.I., Feliu C. 2007: Crest-like bodies in the spermatozoon of Hymenolepididae cestodes from Iberian rodents. Rev. Ibér. Parasitol. 67: 27-33.

Miquel J., Świderski Z., Foronda P., Torres J., Feliu C. 2009a: Ultrastructure of spermatogenesis of Taenia taeniaeformis (Batsch, 1786) (Cestoda, Cyclophyllidea, Taeniidae) and comparison of spermatological characters in the family Taeniidae Ludwig, 1886. Acta Parasitol. 54: 230-243.

Miquel J., Świderski Z., Marchand B. 2005b: Spermatological characters in the Dipylidiidae Stiles, 1896 (Cestoda, Cyclophyllidea). Acta Parasitol. 50: 65-73.
Miquel J., Świderski Z., MŁocicki D., Eira C., Marchand B. 2005a: Ultrastructure of spermatogenesis of the anoplocephalid cestode Gallegoides arfaai (Mobedi et Ghadirian, 1977) Tenora et Mas-Coma, 1978. Acta Parasitol. 50: 132-144.

Miquel J., Torres J., Foronda P., Feliu C. 2009b: Spermiogenesis and spermatozoon ultrastructure of the davaineid cestode Raillietina micracantha (Fuhrmann, 1909). Acta Zool. (Stockh.) (In press.)

Mokhtar-Maamouri F., Azzouz-Draoui N. 1990: Spermatogenèse et ultrastructure du spermatozoïde de Nematotaenia chantalae Dollfus, 1957 (Cestoda, Cyclophyllidea, Nematotaeniidae). Ann. Parasitol. Hum. Comp. 65: 221-228.

Niaye P.I., Agostini S., Miquel J., Marchand B. 2003b: Ultrastructure of spermiogenesis and the spermatozoon in the genus Joyeuxiella Fuhrmann, 1935 (Cestoda, Cyclophyllidea, Dipylidiidae): comparative analysis of $J$. echinorhynchoides (Sonsino, 1889) and J. pasqualei (Diamare, 1893). Parasitol. Res. 91: 175-186.

Ndiaye P.I., Miquel J., Marchand B. 2003a: Ultrastructure of spermiogenesis and spermatozoa of Taenia parva Baer, 1926 (Cestoda, Cyclophyllidea, Taeniidae), a parasite of the common genet (Genetta genetta). Parasitol. Res. 89: 34-43.

Świderski Z. 1968: The fine structure of spermatozoon of sheep tapeworm, Moniezia expansa (Rud., 1810) (Cyclophyllidea, Anoplocephalidae). Zool. Pol. 18: 47-48.

ŚWIDERSKI Z. 1970: An electron microscope study of spermatogenesis in cyclophyllidean cestodes with emphasis on the comparison of the fine structure of mature spermatozoa. J. Parasitol. 56: 337-338.

ŚwIDERSKi Z. 1986: Three types of spermiogenesis in cestodes. Proceedings of the XIth International Congress on Electron Microscopy, Kyoto, Japan, pp. 2959-2960.

Świderski Z., Salamatin R.V., Tкach V.V. 2000: Electron microscopical study of spermatozoa of the cestode Dilepis undula (Cyclophyllidea, Dilepididae). Vest. Zool. 34: 93-97.

Willms K., Caro J.A., Robert L. 2003: Ultrastructure of spermatogonia and spermatocyte lobules in Taenia solium strobilae (Cestoda, Cyclophyllidea, Taeniidae) from golden hamsters. Parasitol. Res. 90: 479-488.

Willms K., Robert L., Jimenez J.A., Everhart M., Kuhn R.E. 2004: Ultrastructure of spermiogenesis and the spermatozoon in Taenia crassiceps strobilae WFU strain (Cestoda, Cyclophyllidea, Taeniidae) from golden hamsters. Parasitol. Res. 93: 262-267.

Yoneva A., Georgieva K., Mizinska Y., Georgiev B.B., StoitsOVA S.R. 2006a: Ultrastructure of spermiogenesis and mature spermatozoon of Skrjabinoporus merops (Cyclophyllidea, Metadilepididae). Acta Parasitol. 51: 200-208.

Yoneva A., Georgieva K., Mizinska Y., Nikolov P.N., Georgiev B.B., Stoitsova S.R. 2009: Ultrastructure of spermiogenesis and mature spermatozoon of Anonchotaenia globata (von Linstow, 1879) (Cestoda, Cyclophyllidea, Paruterinidae). Acta Zool. (Stockh.) (In press.)

Yoneva A., Miquel J., Świderski Z., Georgieva K., Mizinska Y., Georgiev B.B. 2006b: Ultrastructure of spermiogenesis and mature spermatozoon of Angularella beema (Clerc, 1906) (Cestoda, Cyclophyllidea, Dilepididae). Acta Parasitol. 51: 264-272.

Yoneva A., Świderski Z., Georgieva K., Nikolov P.N., Mizinska Y., Georgiev B.B. 2008: Spermiogenesis and sperm ultrastructure of Valipora mutabilis Linton, 1927 (Cestoda, Cyclophyllidea, Gryporhynchidae). Parasitol. Res. 103: 1397-1405. 